\title{
What are the Top 10 Unanswered Questions in Molecular Plant-Microbe Interactions?
}

\author{
Jeanne M. Harris, ${ }^{1+}{ }^{+}$Peter Balint-Kurti, ${ }^{2}$ Jacqueline C. Bede, ${ }^{3}$ Brad Day, ${ }^{4}$ Scott Gold, ${ }^{5}$ Erica M. Goss, ${ }^{6}$ \\ Laura J. Grenville-Briggs, ${ }^{7}$ Kathryn M. Jones, ${ }^{8}$ Aiming Wang, ${ }^{9}$ Yuanchao Wang, ${ }^{10}$ Raka M. Mitra, ${ }^{11}$ \\ Kee Hoon Sohn, ${ }^{12}$ and Maria Elena Alvarez ${ }^{13}$ \\ ${ }^{1}$ Department of Plant Biology, University of Vermont, Burlington, VT 05405, U.S.A. \\ ${ }^{2}$ USDA-ARS, Plant Science Research Unit, Raleigh NC, and Dept. of Entomology and Plant Pathology, NC State University, \\ Raleigh, NC 27695-7613, U.S.A. \\ ${ }^{3}$ Department of Plant Science, McGill University, Ste-Anne-de-Bellevue, Quebec H9X 3V9, Canada \\ ${ }^{4}$ Department of Plant, Soil and Microbial Sciences, Michigan State University, East Lansing, MI 48824, U.S.A. \\ ${ }^{5}$ Plant Pathology Department, University of Georgia, USDA-ARS, Athens, GA 30605-2720, U.S.A. \\ ${ }^{6}$ Plant Pathology Department and Emerging Pathogens Institute, University of Florida, Gainesville, FL 32611, U.S.A. \\ ${ }^{7}$ Department of Plant Protection Biology, Swedish University of Agricultural Sciences, SE-230 53 Alnarp, Sweden \\ ${ }^{8}$ Department of Biological Science, Florida State University, Tallahassee, FL 32306, U.S.A. \\ ${ }^{9}$ London Research and Development Centre, Agriculture and Agri-Food Canada, London, ON N5V 4T3, Canada \\ ${ }^{10}$ Department of Plant Pathology, Nanjing Agricultural University, and Key Laboratory of Integrated Management of Crop \\ Diseases and Pests (Ministry of Education), Nanjing 210095, China \\ ${ }^{11}$ Biology Department, Carleton College, Northfield, MN 55057, U.S.A. \\ 12 Department of Life Sciences, Pohang University of Science and Technology and School of Interdisciplinary Bioscience and \\ Bioengineering, Pohang University of Science and Technology, Pohang 37673, Korea \\ ${ }^{13}$ Centro de Investigaciones en Química Biológica de Córdoba, CIQUIBIC, CONICET, Departamento de Química Biológica \\ Ranwel Caputto, Facultad de Ciencias Químicas, Universidad Nacional de Córdoba, Córdoba X5000HUA, Argentina
}

Accepted 5 October 2020.

\begin{abstract}
The past few decades have seen major discoveries in the field of molecular plant-microbe interactions. As the result of technological and intellectual advances, we are now able to answer questions at a level of mechanistic detail that we could not have imagined possible 20 years ago. The MPMI Editorial Board felt it was time to take stock and reassess. What big questions remain unanswered? We knew that to identify the fundamental, overarching questions that drive our research, we needed to do this as a community. To reach a diverse audience of people with different backgrounds and perspectives, working in different areas of plant-microbe interactions, we queried the more than 1,400 participants at the 2019 International Congress on Molecular Plant-Microbe Interactions meeting in Glasgow. This group effort resulted in a list of ten, broad-reaching, fundamental questions that influence and inform our research. Here, we introduce these Top 10 unanswered questions, giving context and a brief description of the issues. Each of these questions will be the subject of a detailed review in the coming months. We hope that this process of reflecting on what is known and unknown and identifying the themes that underlie our research will provide a framework to use going forward,
\end{abstract}

${ }^{\dagger}$ Corresponding author: J. M. Harris; Jeanne.harris@uvm.edu

*The $\boldsymbol{e}$-Xtra logo stands for "electronic extra" and indicates a supplementary table is published online.

The author(s) declare no conflict of interest.

Copyright $\odot 2020$ The Author(s). This is an open access article distributed under the CC BY 4.0 International license. giving newcomers a sense of the mystery of the big questions and inspiring new avenues and novel insights.

Keywords: abiotic stress, cell death, effector-triggered immunity, MAMP-triggered immunity, nonhost resistance, phytobiome, plant defense, plant immunity, plant-microbe interactions, symbiosis

Plants are surrounded by a world of microbes. Their interactions influence plant growth and development, microbial success, shape natural ecosystems, and have profound implications for agriculture and human health. Contributions from scientists around the world have helped reveal some of the diverse molecular dialogues and metabolic connections between plants and microbes, including their evolution and their role in nature and agriculture. The past few decades have seen tremendous technical advances in the form of incredibly finescale expression analyses, quantitative biochemical and cell biology-based studies, high-throughput phenotyping of roots and shoots, including single cell analyses, and the development of sensitive methods to detect and localize metabolites and metals within both plants and microbes, that have made it possible to address questions we have not been able to before. Powerful genetic tools, such as CRISPR, paired with wholegenome sequencing and expression analysis, means that the genomes of both plants and their associated microbes are now readily accessible and insights that would previously have taken years can now take days or months. Additionally, and as evidenced by recent examples of "crowd sourcing" efforts, the availability of these data to the broader community mean that we can begin the important work of translational studies in a significantly faster timescale. 
In parallel with these changes, our awareness of the microbiome enables us to think differently about plants and the complex microbial world they inhabit. Instead of trying to keep plants and media sterile and focus exclusively on binary interactions, we now welcome soil and leaf microbial communities for what they tell us about the intimate communications between the plant host, its environment, and the microbiome (Rodriguez et al. 2019).

The MPMI journal has been pleased to be a part of these exciting advances. However, much of the intimate interactions of plants and microbes remain a mystery. So much has been learned and accomplished, but there is much that we still do not know. What are the big unanswered questions that remain? The Editorial Board of MPMI want to shift the focus forward, to identify the fundamental, overarching questions in our field. In view of rapid technological advances and important new discoveries paired with the sobering prospect of a rapidly changing planet, we felt that the moment to do this was now.

\section{ENGAGING THE RESEARCH COMMUNITY}

To identify the important, unsolved questions that drive us, we realized that we needed to cast a broad net, querying people with expertise across a broad spectrum of molecular plantmicrobe interactions. The biennial International Congress on Molecular Plant-Microbe Interactions (IC-MPMI), which met in Glasgow, Scotland last year, was the ideal venue. With over 1,400 people attending from 52 countries and with a variety of research interests, we were able to reach a wide swath of the community and tap into the excitement, enthusiasm, and creativity of this diverse group.

Our idea was to brainstorm, as a community, to identify the top 10 unanswered questions in MPMI. With the support of the IC-MPMI meeting organizers and the IS-MPMI board of directors, the search for the Top 10 questions in MPMI was introduced in the welcome address by Regine Kahmann and in a flyer given to each attendee as they registered. To include people who did not attend the meeting, we also announced this effort in an article in the IS-MPMI Interactions newsletter and on social media as \#Top10MPMI.

\section{The MPMI podcast Microgreens.}

To further engage the community on this issue, we initiated a podcast, Microgreens, where we could present the idea of the search for the Top 10 MPMI questions in a more conversational way. Host and producer Raka Mitra conducted phone interviews, in advance of the meeting, with graduate students and professors, asking them their thoughts about the important, unanswered questions in MPMI. Dr. Mitra crafted a short, twominute introduction to the idea of the search for the Top 10 questions in MPMI that was released prior to the meeting and helped to engage both meeting attendees and the wider community. For many of the scientists interviewed, this was their first exposure to the search for the Top 10 questions in MPMI, and thus, they were able to spread the word.

\section{Gathering the questions.}

Even before the conference began, people started posting questions on Twitter and e-mail and in podcast interviews. At the IC-MPMI conference itself, poster boards were available with sticky notes on which attendees could write and post questions (Fig. 1). Conference attendees enthusiastically embraced this initiative, posting questions even on the first day and discussing the idea with colleagues. There were discussions, brainstorming lunches, and many, many ideas posed in talks and on social media. In addition to these efforts, Dr. Mitra recorded conversations with additional attendees to capture their voices and perspectives. All the questions posed in talks, discussions, interviews, and on social media and discussion boards became a part of our growing collection of unanswered questions.

\section{Voting on the Top 10 questions.}

In all, we collected over 170 questions. The next task was to curate the list so that we could present a manageable set of questions for people to vote on. To start, a subgroup of the $M P M I$ editorial board reviewed questions, first removing those that were political or social ("What will it take to get Europe to accept GM crops?") or too focused. We then grouped questions that were similar to each other, choosing only one from each group for our final list, leaving us with 55 questions. We further reduced the list, retaining the 33 questions (Supplementary Table S1) that we felt were broadest in scope and that together represented the breadth of topics and covered a range of scales, molecular, cellular, physiological, evolutionary, and ecological. In total, these questions were all deeply interesting, timely, and unanswered.

We posted the list of 33 questions on the conference app and asked people to choose their top five questions. The survey was open for approximately $18 \mathrm{~h}$. During that time, 347 people voted, or approximately $25 \%$ of the congress attendees.

\section{THE TOP 10 QUESTIONS!}

The Top 10 Questions selected by the IC-MPMI community covered a broad range of questions reflecting the range of original questions submitted and the varied research presented at the conference (Table 1). In fact, five of the Top 10 questions were generally applicable to interactions between plants and microbes. Rather than focusing on a specific interaction (e.g., plantbacterial, plant-fungal) or type of relationship (i.e., pathogenic, symbiotic, or commensal), these Top 10 questions framed issues that are relevant to many different kinds of interactions (Fig. 2). Three of the first four questions reveal our desire to understand the way in which the biotic (questions 1 and 4) and abiotic (question 2) environment influence specific plant-microbe interactions. Question 3 is driven by the need to translate our findings about molecular plant-microbe interactions gathered from model systems and in laboratory settings to crops and to a field setting. This question is strongly connected to question 10 , which asks how binary plant-microbe interactions hold in an ecological context. The other five questions focus on plant disease at a mechanistic level, pushing the current limits of our knowledge. There was almost equal interest in questions 5 and 6. Question 5 asks us to re-examine the framework we have built for thinking about the relationship between effector-triggered immunity (ETI) and pathogen-associated molecular patterntriggered immunity (PTI) signaling. Question 6 reflects a strong interest in understanding the various mechanisms of nonhost resistance, which could potentially be used to strengthen plant defenses to the disease-causing microbes to which they are susceptible. Question 7 draws attention to cell death, reminding us that the mechanism by which resistance proteins activate cell death is still unknown. The very simplicity of questions 8 and 9 point to their fundamental nature and reflects the ongoing mystery of how novel virulence activities are acquired (question 9) and the puzzle of how the number of effectors needed by a pathogen to be successful can vary by orders of magnitude (question 8).

Here, we introduce the Top 10 questions, giving context and a brief description of the issues. A series of in-depth reviews, one for each question, will be published in MPMI over the next several months. Our first review, on question 6, What is the Molecular Basis of Nonhost Resistance? kicks off the series (Panstruga and Moscou 2020). We hope that this article will help to focus the attention of our research community on the central questions that 
we face and that it will inspire new scientists to engage with these top questions, and help us to build the answers, one piece at a time.

\section{Question 1: How do plants engage with beneficial microorganisms while at the same time restricting pathogens?}

Plants are surrounded by microbes, some beneficial and some pathogenic-interacting with both at the same time is a precarious balancing act! To navigate this microbial world, the plant must optimize and nurture beneficial interactions while simultaneously reducing interactions that lead to disease. Plants have evolved numerous, sensitive mechanisms for detecting microbes and activating defense responses (Peng et al. 2018). However, an overactive defense response can have undesired consequences: limiting interactions with beneficial microbes.

Balancing the plant response to beneficial versus pathogenic micro-organisms is challenging, because the first layer of recognition by the plant involves generic features, such as flagellin or cell-wall components. These microbe-associated molecular patterns (MAMPs) are conserved features of many microbes, shared by pathogens and symbionts alike. Recognition of MAMPs by cell surface receptors triggers the first layer of defense. However, microbial symbionts such as rhizobia, Frankia spp., and mycorrhizal fungi, bypass defenses and extensively infect their plant hosts (Berrabah et al. 2019). These are not just conditional interactions but, rather reflect life-asusual for their plant partners.

What are the impacts of routinely lowering their defenses to allow symbiotic partners in? Does the lowering of defenses to allow symbiont entry reduce defense against pathogens? It turns out that the answer is not simple, reflecting both the diversity of plants and the complexity and variety of the microbial world surrounding them. There are certainly examples of increased susceptibility of a host to a pathogen, such as the increased the severity of Botrytis cinerea in tobacco plants whose roots were colonized by mycorrhizal fungi (Shaul et al. 1999). However, examples abound in which symbiotic associations with mycorrhizal fungi or rhizobia induce resistance against pathogens, nematodes, and insects (Conrath et al. 2006; Costa et al. 2020; Smigielski et al. 2019). Conversely, tuning up defenses can inhibit infection by beneficial microbes. For example, jasmonate signaling limits infection by some necrotrophic pathogens and herbivores (Zhang et al. 2017) but also limits infection by beneficial rhizobium bacteria (Sun et al. 2006).

How are the responses to beneficial and pathogenic microbes coordinated? To modulate responses so that defenses can be raised and lowered as needed, defense responses must be finetuned both at the spatial and at the temporal level. What are the mechanisms? We know it must be at least somewhat conserved, because treatment with the rhizobial nodulation signal, i.e., Nod factor, dampens the innate immune response in both legumes and nonlegumes, including Arabidopsis, which is not a host for beneficial rhizobia (Liang et al. 2013).

Looking more broadly, the microbiome, comprising those microbes that live on, around, and within plants, manipulates plant physiology and defense, priming plants for future encounters with pathogens and insects, increasing their resilience (Pieterse et al. 2014). How do interactions within the
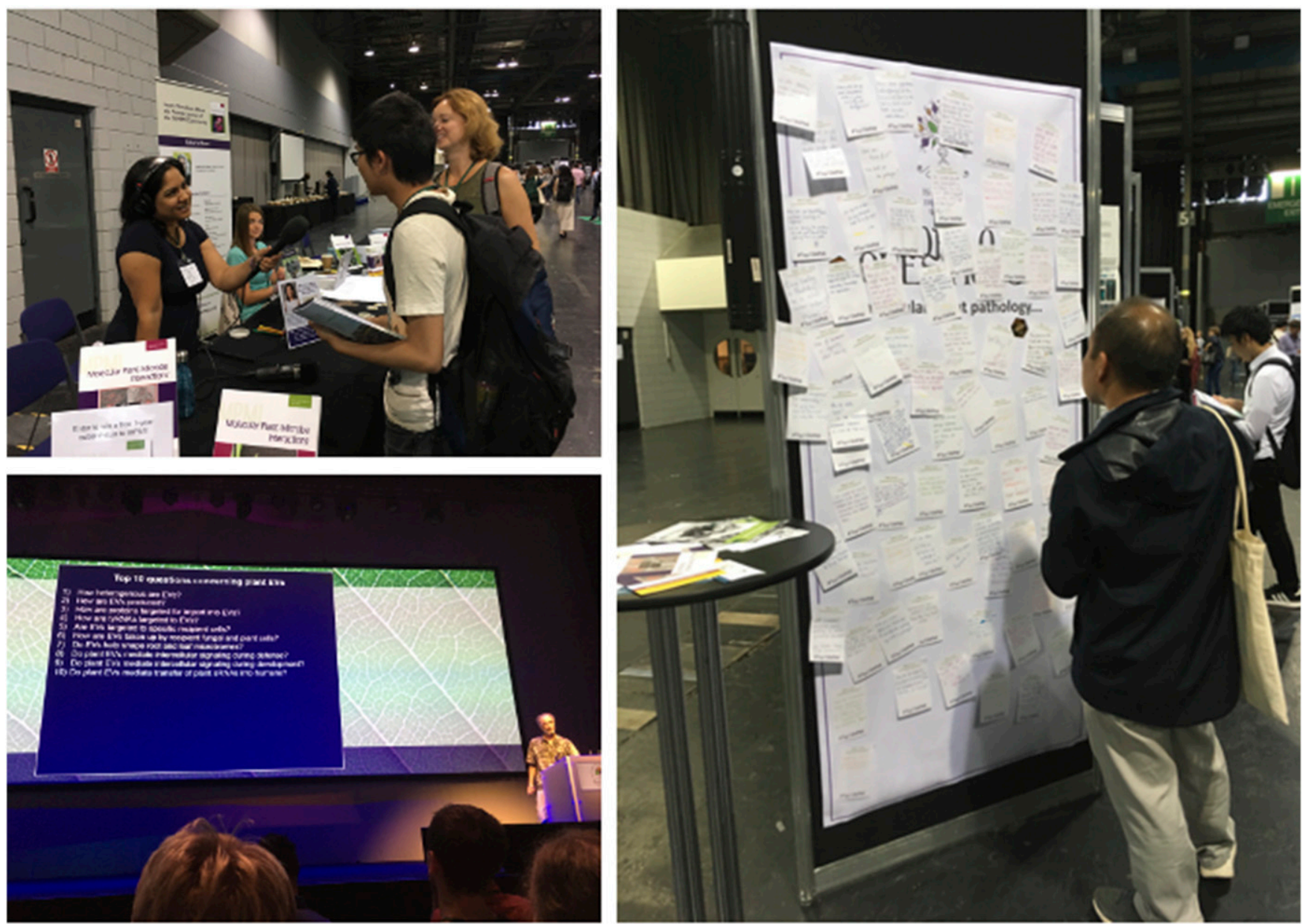

Fig. 1. Gathering unanswered research questions from the community at the IC-MPMI in Glasgow, U.K., July 2019. 
microbiome and between the microbiome and the plant alter the timing and magnitude of the plant response to pathogens and other micro-organisms? These questions are explored explicitly in question 4, which addresses microbe-microbe interactions and question 10 , which considers binary plantmicrobe interactions in an ecological context.

In summary, to navigate life in a complex world filled with microbes, plants must strike a careful balance between repelling and promoting interactions with the microbial world. The incredible diversity of microbes and plants and the interactions

Table 1. The Top 10 unanswered questions in MPMI

\begin{tabular}{|c|c|c|}
\hline Question no. & Question & No. of votes \\
\hline 1 & $\begin{array}{l}\text { How do plants engage with beneficial } \\
\text { microorganisms while at the same time } \\
\text { restricting pathogens? }\end{array}$ & 157 \\
\hline 2 & $\begin{array}{l}\text { How does abiotic stress, such as climate } \\
\text { change, influence plant-microbe } \\
\text { interactions? }\end{array}$ & 108 \\
\hline 3 & $\begin{array}{l}\text { How can we translate basic research into } \\
\text { emerging crop plants? }\end{array}$ & 106 \\
\hline 4 & $\begin{array}{l}\text { How do microbe-microbe interactions affect } \\
\text { plant-microbe interactions? }\end{array}$ & 97 \\
\hline 5 & $\begin{array}{l}\text { Does effector-triggered immunity (ETI) } \\
\text { potentiate and restore pathogen-associated } \\
\text { molecular pattern-triggered immunity } \\
\text { (PTI)-or is there really a binary distinction } \\
\text { between ETI and PTI? }\end{array}$ & 96 \\
\hline 6 & $\begin{array}{l}\text { What is the molecular basis of nonhost } \\
\text { resistance? }\end{array}$ & 96 \\
\hline 7 & $\begin{array}{l}\text { How do resistance proteins activate cell } \\
\text { death? }\end{array}$ & 78 \\
\hline 8 & $\begin{array}{l}\text { Why do some pathogens need so many } \\
\text { effectors when others need a few? }\end{array}$ & 74 \\
\hline 9 & $\begin{array}{l}\text { How do pathogens evolve novel virulence } \\
\text { activities? }\end{array}$ & 65 \\
\hline 10 & $\begin{array}{l}\text { How do observations of binary plant-microbe } \\
\text { interactions hold in an ecological context? }\end{array}$ & 64 \\
\hline
\end{tabular}

among these in different contexts reveal the complexity of this problem and the importance of this question.

\section{Question 2: How does abiotic stress influence plant-microbe interactions?}

As our climate changes, the earth will experience increasingly extreme weather events, including an increase in baseline temperatures. As temperatures rise, plants in some regions will experience more dryness and increasing salinity in the soil, while others will experience increased frequency of flooding and powerful storms (Sherwood and $\mathrm{Fu}$ 2014). Simultaneously, atmospheric $\mathrm{CO}_{2}$ levels are increasing, which will lead to altered carbon and nitrogen metabolism in both plants and microbes. These rapidly changing climatic events are driving us to answer this question. Increasing our understanding of the way abiotic stress influences plant-microbe interactions at a mechanistic level will help us to make predictions about how future environmental changes will affect plants and will also provide insight into how plants coordinate multiple inputs from the environment to modulate growth, development, and defense.

We know that interactions between plants and microbes are influenced by environmental factors. However, disease outbreaks are often linked to weather conditions as well, with rain and humidity stimulating conditions for many devasting diseases, such as late blight (Johnson et al. 2009), and dry or saline conditions at times inhibiting colonization of plant hosts by beneficial micro-organisms, such as rhizobia (Zahran 1999). Recent evidence also suggests that elevated $\mathrm{CO}_{2}$ levels can result in shifts in hormone levels induced by biotic stress, namely an increase in pathogen-induced salicylic acid and a decrease in wound-induced jasmonates (Martinez Henao et al. 2020; Mhamdi and Noctor 2016).

Conversely, there are many examples of interactions with microbes that increase resistance of the plant host to adverse conditions. Formation of the arbuscular mycorrhizal symbiosis

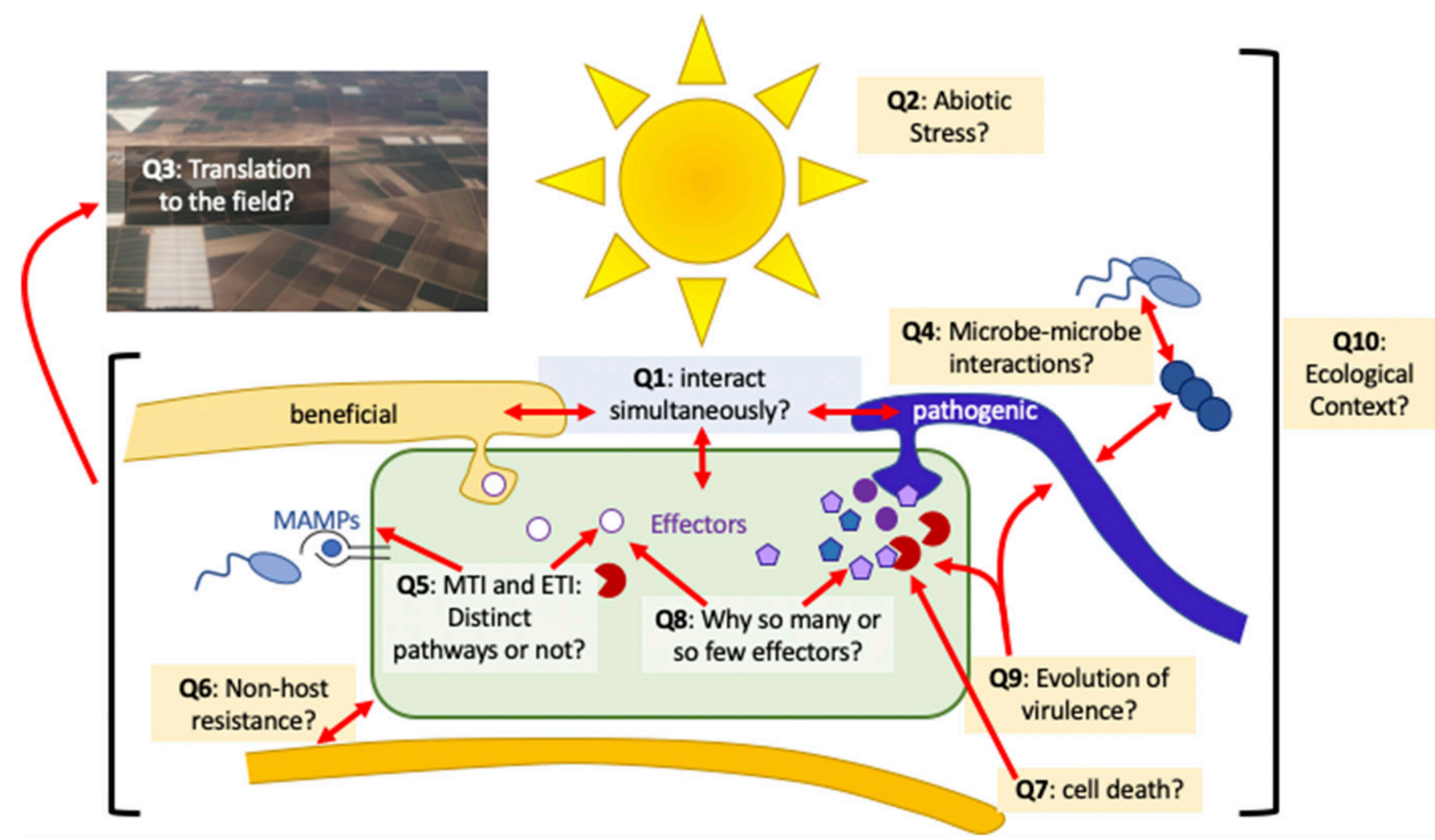

Fig. 2. The landscape of the Top 10 unanswered questions in MPMI. 
confers resistance to drought and salinity as well many as other stresses (Kivlin et al. 2013; Evelin et al. 2019). The resilience it confers may be as important as nutrient delivery to the host and may have been a driver for plant colonization of land (Field and Pressel 2018). The tripartite endophytic association between a grass, a fungus, and a virus allows some grasses to tolerate hot geothermal soils (Marquez et al. 2007). What other plantmicrobe interactions confer stress tolerance on the host?

These are just a few instances where we have some knowledge about how the interaction between plants and microbes is affected by abiotic stress or how microbes affect host response to abiotic stress. For most interactions, we have very little idea about mechanism or even effect. We do know that microbes will expand their geographic ranges in response to changing environments and that increasing temperatures increase metabolic rates. Models integrating climate change with insect metabolism and population growth predict dramatic increases in crop loss in response to a small increase in temperature (Deutsch et al. 2018). How will abiotic stresses affect other plant-microbe interactions? How do plant-microbe interactions affect host response to abiotic stress? When we extend this line of questioning to consider nonbinary interactions, the questions multiply. What happens to plant-microbe interactions in the presence of more than one environmental stress? In the natural world, plants associate with more than one microbe at a time. How does abiotic stress affect interactions within the microbial community to affect plant health? Recent work by Berens and colleagues (2019) demonstrates complex interactions between abiotic stress, plant development, and biotic interactions, both with plant disease-causing organisms and with the leaf microbiome. The interactions between plants, microbes, and environmental conditions described here hint at the enormous complexity and diversity of interactions that occur in the natural world. This is an area ripe for exploration and the findings will have enormous importance as we face a changing world.

\section{Question 3: How can we translate basic research into emerging crop plants?}

Significant advances in our understanding of plant-microbe interactions have been made at the molecular, genetic, and biochemical level over the past few decades. Much of this has been achieved in the lab, where plants were grown in controlled conditions on plates or in pots in growth chambers or greenhouses, and in many cases, the species evaluated were not crop plants. How can these findings be translated to real-world agricultural systems? This question is on the minds of many. Translating basic research into crop plants has two big hurdles. First, taking knowledge gained in the study of one plant system and moving it to another; second, studying these questions in the field, where the environment, both biotic and abiotic, as well as human actions confound the function and activity of the physiological processes driving plant growth, development, and their interactions with microbes. Importantly, this question integrates many of the Top 10 questions that address the complexity of the natural environment, where multiple microbes are interacting simultaneously with the plant and with each other and where the abiotic environment affects everything (questions $1,2,4$, and 10).

Translating basic research to the field is a perennial question, so why was there such a sense of urgency at the congress? The driving motivation for this question is an increasing world population but decreasing arable land, due to a combination of erosion, urbanization, and desertification (Fitton et al. 2019; Panagos et al. 2018). The loss of arable land is intrinsically connected to planetary change - increased heat leads to drier land with less available water and which is more prone to fire (Sherwood and $\mathrm{Fu}$ 2014). The rapid pace of climate change also means an expansion of the geographic ranges of microbes, opening the possibility of new interactions between crops and microbes that will provide a challenge to farmers (Deutsch et al. 2018).

What we have learned in model organisms and in lab studies gives us an important foundation and framework for how plants and microbes detect each other, how they communicate, and, importantly, how they respond to these dialogues. This foundation allows us to move to other plants, numerous environmental conditions, and the limitless combinations of each. Indeed, new technologies, including numerous portable tools, make it possible to sample and sequence multiple pathogen samples in a field or region to better understand disease outbreaks and spread while they are happening. For example, we now have the ability to test whether insights gained from lab studies can be translated into management practices that reduce disease. Similarly, insights from laboratory and model organism studies that do not directly translate to field settings present opportunities to examine, reshape, and redefine the complexity of interactions that exist across changing environments and landscapes. With this, it is possible to develop new, hopefully improved, agricultural management practices that more appropriately align with crop-based plant-microbe interactions. Finally, field studies of perennial plants can help us to better understand plant-microbe interactions in plants that grow for years, experiencing seasons, variations in climate, and repeated and varied interactions with microbes, animals, humans, and other plants.

In summary, recent technological advances, coupled with an increasing awareness of the microbiome and our changing climate, make this question one of utmost importance and urgency. As we transition from model organisms and laboratory settings into different plants and crops, we will undoubtedly encounter unknown microbes, including those recalcitrant to common culturing techniques, and new interactions and weather patterns, and together, these factors will all lead to a greater appreciation of the complicated environments and processes that influence where and how plants grow. Although the challenges are great, research is moving in new, exciting directions, and field-based applications, such as quantitative phenotyping methods, coupled with remote sensing, and changing the definition of "Big Data." Increased computational resources mean investigators now have the ability to store, manage, share, and analyze large datasets, working with colleagues around the world, in real time. Using computational approaches to examine the composition of microbial communities and their interactions with each other and with plants, under different conditions, raises the possibility of tailored microbiomes for different crops in different environments (Rodriguez et al. 2019). Thus, in beginning to address this complex question, we find we are only beginning to scratch the surface of understanding the possibilities that lie before us. What new tools or approaches can we develop to make it possible to translate our knowledge of molecular plant-microbe interactions from the lab to the field?

\section{Question 4: How do microbe-microbe interactions affect plant-microbe interactions?}

Microbes interact at every level of the phytobiome, impacting plant health in sometimes predictable and sometimes stochastic ways. High-throughput sequencing and advances in computing power have opened a window into the incredible diversity of the rhizosphere and phyllosphere microbiome. For example, the soil microbiome is a tangled web of millions of species and it will take decades of intense and creative research to begin to understand the potentially billions of individual microbemicrobe interactions, a subset of which impact plant health.

Our focus is usually the interaction between a plant and microbe, but microbes do not live in a vacuum and their 
interactions, though poorly understood, undoubtedly impact crucial aspects of plant-microbe interactions, including, but not limited to, abundance and quality of primary inoculum and formation of disease complexes. Pathogen primary inoculum is a critical feature of plant disease epidemics. In soilborne disease, exploration of suppressive soils is a classic example of the impact that the soil microbial community has on disease outcomes (Schlatter et al. 2017). The development of microbiome symbiotic inoculants is progress along these lines.

While research focused on gaining a deeper mechanistic understanding of the functions of single effectors or resistance genes in binary plant-microbe interactions illuminates our understanding of the specificity of recognition, there are doubtless missed opportunities when microbe-microbe interactions are removed (Hassani et al. 2018). For example, processes and signals such as quorum-sensing, secreted effectors, antibiotics found in soil, or competition for scarce nutrients, shape additional factors that drive competition or cooperation between microbes. Not surprisingly, these factors significantly influence both the nature and intensity of plant-microbe interactions. Such examples include the antagonistic interaction between two maize seed endophytes, which leads to reduced virulence of one on the host plant (Gao et al. 2020).

Biological control measures rely on deep understanding of inter- and intraspecies microbe-microbe interactions. Historically, the most successful biological controls have been single species with characterized interactions with their target pathogen or pathogens. The use of microbiome additives introduces high levels of complexity to the system but, as has been demonstrated, we may not need to understand everything to generate beneficial amendments. However, we will likely be orders of magnitude more efficient in our microbial additive product development with a full understanding of the phytobiome and its multitude of interactions.

\section{Question 5: Does ETI potentiate and restore PTI-or is there really a binary distinction between ETI and PTI?}

Plants recognize microbes in their environment by detecting the molecules that comprise various external features, such as flagellin from bacterial flagella, peptidoglycan and lipopolysaccharides from bacterial cell walls, chitin from fungi, and heptaglucans from oomycetes (Ranf 2017). Recognition of these MAMPs by plant receptors turns on MAMP-triggered immunity (MTI) (Note: PAMP is the original name for MAMP, and PTI is equivalent to MTI). Since these general surface features are shared by most beneficial and neutral microbes as well as pathogens, this provides a challenge for the plant to muster an appropriate level of response (the problem considered in question 1). Many microbes also produce effectors or virulence factors that they deliver into the plant host. Some of these effectors interact with components of the plant defense system to dampen the MTI response (Jones and Dangl 2006). Recognition of some of these effectors by the plant defense system turns on ETI (Bialas et al. 2018). The zigzag model (Fig. 3) provides a framework to think about the layers of this interaction, the repeated signaling between plant and microbe and the ratcheting up of the defense response as this process continues (Jones and Dangl 2006). The zigzag model is widely used to explain and discuss plant immunity signaling.

MTI and ETI are often considered to have distinct starting points, MAMP recognition for MTI and effector recognition for ETI. However, this distinction is blurred by the fact that some effectors are detected intracellularly while others are detected extracellularly, often sharing the same coreceptors as MAMP receptors (Ma and Borhan 2015; Postma et al. 2016). Downstream of these recognition processes, components, such as mitogen-activated protein kinase cascades and hormone signaling, are shared, and defense responses overlap in time (Peng et al. 2018). If MTI and ETI share coreceptors and downstream signaling components, are they really distinct? If we view them as two distinct pathways but they actually are intertwined, will we miss something? Evidence is already emerging that MTI and ETI are more closely intertwined than predicted by classical models of these pathways ( $\mathrm{Ngou}$ et al. 2020).

What is interesting about question 5 is that is asks whether the way we frame an idea affects the way we address it. Why is this a question? Why does the way we frame an idea matter to the way we design our experiments?

The distinction between MTI and ETI has been a useful framework for thinking about defense and explaining plant immunity. But if we framed this idea differently, would we ask different questions about it? Often, we do not take the time to step back and look at a convenient framework we've constructed but, rather, just use it. The fact that this question rose to number 5, reflects a strong sense in the community that it is time to re-envision the framework we use to describe and think about plant immune signaling.

Although MTI and ETI were originally identified during the study of plant disease, in fact, microbial production of effectors to manipulate the host plant appears to be a general feature of plant-microbe interactions and plays important roles in symbiotic interactions (Wang et al. 2018) as well as pathogenic. Since type III secretion systems, used to deliver effector molecules directly into the host cytoplasm, are widely transferred between microbes via horizontal gene transfer (Naum et al. 2009), it is likely that we will find microbiome-produced effectors and subsequent plant responses as part of a normal response to the plant microbiome. Now that we have a sense of the enormity of the plant-microbe interactions that the plant is simultaneously engaging with at any given moment, it becomes even more imperative to take a step back and rethink the way we frame MAMP and effector response signaling. And, perhaps, this altered framework will result in new experiments and novel insights.

\section{Question 6: What is the molecular basis of nonhost resistance?}

Most plants are resistant to most plant pathogens and no plant pathogens can infect all plant hosts. Nonhost resistance can be defined as "resistance shown by an entire plant species against all known genetic variants (or isolates) of a specific parasite or pathogen" (Heath 1985; Lipka et al. 2008) and can be thought of as a broad-spectrum plant defense. Nonhost resistance is widespread and durable. By what mechanism do nonhosts resist these pathogens so completely? Can they be extended to host plants to reduce disease symptoms and spread?

The pathogenesis process requires the pathogen to successfully complete a number of complicated steps (Thordal-Christensen 2003), such as dissemination, attachment and penetration of the host, evasion of preformed, inducible, and recognitionbased defense responses, and nutrient uptake, growth, and reproduction in the host. The failure of an entire pathogen species to successfully complete any one of these steps on a host species can lead to nonhost resistance. Thus, the mechanism by which nonhost resistance is conferred would be expected to vary widely depending on the specific interaction that is considered.

Nonhost resistance is a problematic concept since it is defined by the absence rather than the presence of an observation. Even in the case of the most intensively studied plant-pathogen systems, we have observed only a tiny fraction of all possible host genotype $\times$ pathogen isolate interactions. A single observation of a compatible host-pathogen interaction will, by definition, lead to the reclassification of an interaction from 
nonhost resistance to host resistance. This type of reclassification occurs with some regularity, either due to the evolution of new pathogen strains or the emergence of previously unobserved strains. Several important crop diseases, such as wheat blast (Couch et al. 2005) and wheat powdery mildew (Inuma et al. 2007), are caused by pathogens for which the crop had once been considered a nonhost. Thus, any consideration of nonhost resistance should include the caveat that, as a phenomenon, it is vaguely defined and mechanistically diverse.

Nevertheless, the causes of nonhost resistance are of considerable interest, mainly because, notwithstanding the exceptions mentioned above, nonhost resistance is generally relatively durable; in most cases nonhosts remain nonhosts over long periods and large areas. A better understanding of the genetic basis of nonhost resistance may open the door for the utilization of nonhost resistance mechanisms to improve host crop species with durable resistance to devastating pathogens.

\section{Question 7: How do resistance proteins activate} cell death?

While a constellation of proteins confer resistance to plant diseases, the majority are members of a family possessing both nucleotide-binding and leucine rich (NLR) repeat domains (Kourelis and van der Hoorn 2018). Most NLR resistance proteins exist in an inactive state in the cytoplasm and are activated by the direct or indirect recognition of specific pathogen effector proteins. Concomitant with the activation and expression of a multitude of host processes, one of the dominant outputs of this recognition is the activation of a defense response known as ETI, which typically leads to the activation of rapid, localized cell death at the point of pathogen penetration, known as the hypersensitive response (HR) (Balint-Kurti 2019). NLRs are found in almost all higher plants (Baggs et al. 2020) and HR is a widespread resistance phenomenon. As such, it can be elicited via activation of NLRs in response to a variety of biotrophic pathogens, including fungi, bacteria, viruses, insects, nematodes, and even parasitic plants (Balint-Kurti 2019).

The control of host cell death is a key determinant of resistance in many plant-pathogen interactions. Biotrophic pathogens have evolved mechanisms of preventing host cell death since they derive nutrition from living cells (Panstruga 2003), while necrotrophic pathogens produce toxins to kill host cells from which they are able to feed. In some cases, necrotrophic pathogens subvert the resistance mechanisms of

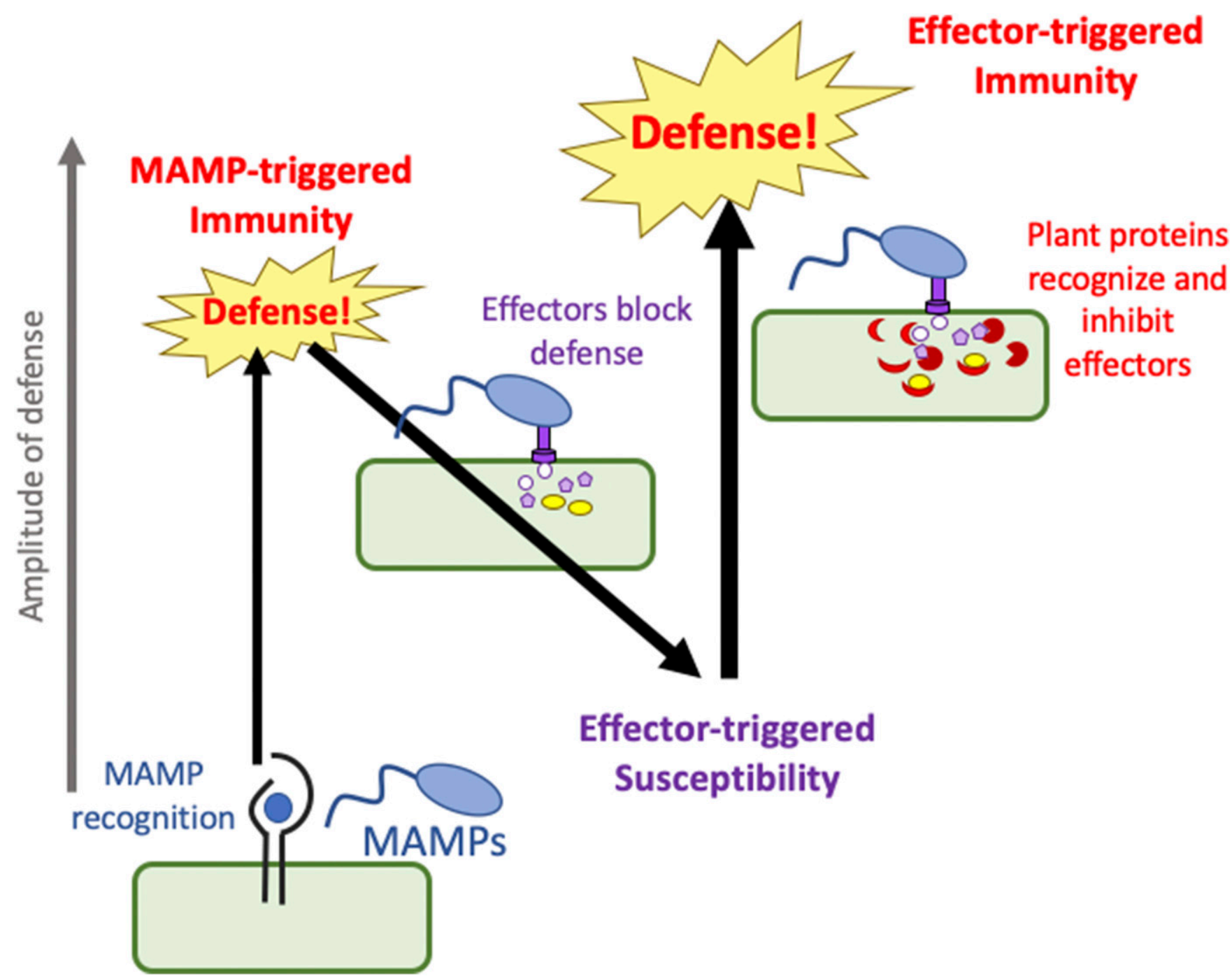

Fig. 3. The zigzag hypothesis as a model for plant defense activation and pathogen virulence. The activation of microbe- or pathogen-associated molecular pattern-triggered immunity (MTI/PTI) represents a broadly converged defense mechanism in plants, mediated by the recognition of conserved microbial features through membrane-localized receptor kinases. Pathogen-delivered effector proteins target numerous physiological processes in the host, including those associated with MTI/PTI activation. This dampening of defense responses leads to effector-triggered susceptibility, which can be counteracted by nucleotide-binding leucine-rich repeat-mediated effector-triggered immunity (ETI). The thickness of the black arrows indicates the strength of the response. In this model, MTI and ETI are framed as distinct pathways. Modified from Jones and Dangl (2006). 
the host, triggering NLRs to induce HR, exploiting a mechanism evolved to provide resistance to one pathogen to confer susceptibility to another (Lorang 2019). HR must also be tightly controlled to allow for optimal plant growth. Aberrant activation or spread of HR can have profound negative effects for plant growth (Chae et al. 2014; Chintamanani et al. 2010). Multiple pathways exist to control the activity of NLRs (BalintKurti 2019)

Remarkably, despite the profound importance of HR, we are still not certain how NLR activation leads to cell death. Numerous screens for genes that suppress HR after NLR activation have tended to identify the same few genes that are thought to act to stabilize NLR complexes rather than as components of a signal transduction pathway (Hubert et al. 2009). This implies a high redundancy in the signaling pathways or that the signaling pathways leading to cell death are extremely short or nonexistent. A recent major advance in this area supports the later scenario. The structure of the activated Arabidopsis NLR resistance (R) protein ZAR1 and its associated proteins was solved, showing that activation leads to the formation of a pentameric oligomer termed a resistosome. A funnel-shaped structure at the center of the resistosome was required for association with the plasma membrane and for subsequent cell death, raising the intriguing possibility that this association may disrupt plasma membrane integrity and trigger cell death (Wang et al. 2019).

This model remains to be proved and much else remains to be understood about the cause of cell death during NLR-mediated HR. NLRs are quite diverse in structure, have a variety of subcellular localizations, and require different interacting proteins (Sun et al. 2020; Wang and Balint-Kurti 2015). Do all NLR R proteins cause cell death by similar mechanisms? ETI is a multifaceted response, including a transcriptional and metabolic response. Are the different facets of ETI induced by separate mechanisms? In some (perhaps many) cases, it appears that activation of NLRs may lead to an ETI that does not include an HR (Laflamme et al. 2020). In these cases, are the consequences of NLR activation fundamentally distinct? The ability to control HR and programmed cell death more precisely may have profound implications for the control of plant disease and would be an important starting point for question 3 , which focuses on translating knowledge acquired from basic research to the field.

\section{Question 8: Why do some pathogens need so many effectors when others need a few?}

To successfully infect a host, pathogens have evolved diverse repertoires of effectors, molecules the microbe delivers to the plant to alter cellular structure, metabolism, or physiology. Many promote the colonization of microbial pathogens by manipulating the host immune system or by protecting pathogens from host defenses. In fact, beneficial microbes also use effectors to manipulate their plant hosts. In the rhizobiumlegume interaction, type III secreted effectors facilitate infection of some hosts, yet can also inhibit infection of others, restricting host range and indicating commonalities in effector use by pathogenic and beneficial microbes (Wang et al. 2018).

One long-standing question is how many host targets need to be overcome by effectors to achieve a successful infection. Although it is clear that some pathogens only deploy a small number of effectors in certain hosts (de Wit 2016; Khan et al. 2018; Lo Presti et al. 2015; Wang and Wang 2018), others have a large set of effectors. Even among members of a genus, the number of effectors produced by different microbes can vary enormously. For example, Phyophthora betacei is predicted to have over 1,000 apoplastic effectors and more than 800 cytoplasmic effectors, whereas $P$. ramorum has slightly more than half as many apoplastic effectors and fewer than one fourth as many predicted cytoplasmic effectors (Rojas-Estevez et al. 2020). In bacteria, an analysis of almost 500 Pseudomonas syringae strains revealed a wide variation in the number of type III secreted effectors they encoded, varying from as low as one to as high as 53 (Dillon et al. 2019). Why is there such a diversity in the number of effectors used by different microbes? How many effectors are needed for the 'arsenal' of a successful pathogen?

Accumulating evidence has supported the hypothesis that many effector genes are under strong selection pressures and evolve rapidly in an 'arms race' between pathogen and host (Baltrus et al. 2011; Friesen et al. 2006; Wang et al. 2011; Ye et al. 2016). There is an enormous diversity among effector proteins in terms of structure, subcellular localizations, and biological functions, e.g., toxins, degradative enzymes, hormones, transcription factors (de Wit 2016; Deng et al. 2017; Khan et al. 2018; Wang and Wang 2018). The function of most predicted effector proteins remains unknown.

Pathogen effector repertoires are linked to genome organization. Effector genes are often over-represented in adaptable genome regions, such as transposable element-rich regions, gene-sparse regions, and conditionally dispensable chromosomes. These regions are likely 'hotbeds' that facilitate gene birth via horizontal transfer, substantial duplications, deletions, and other changes for functional and transcriptional polymorphism (Dong et al. 2015a; Faino et al. 2016; Friesen et al. 2006; Hartmann et al. 2017; Jiang and Tyler 2012; Ma et al. 2010; Möller and Stukenbrock 2017; Savory et al. 2015). Effectors are often lineage-specific, and the family category and size can be highly variable, even among the most closely related pathogen species (Baltrus et al. 2011; Dong et al. 2015b; Jiang and Tyler 2012; Joardar et al. 2005). For example, many oomycete pathogens have several large effector families, e.g., RxLR, CRN, and YxSL[KR] families, which have dozens or even hundreds of members per family (Baxter et al. 2010; Haas et al. 2009; Jiang et al. 2008). Effectors in these families often have distinguishable motifs and conserved structural folds (Boutemy et al. 2011; He et al. 2019), but they are not widely identified in the genomes of other pathogens. RxLR effectors were originally found only in Phytophthora spp. and downy mildews, with a dramatic change of gene numbers among species, e.g., 134 in Hyaloperonospora arabidopsidis (Baxter et al. 2010) and 563 in Phytophthora infestans (Haas et al. 2009). More recently, RxLR genes were found in Pythium species, underscoring the way in which estimates change as tools improve and more diverse species (and strains) are interrogated (Ai et al. 2020).

Host range and lifestyle (biotroph, hemibiotroph, or necrotroph) are other major factors that shape the detailed repertoires of pathogen effectors. Host specialization of pathogens may be due to evolution of individual effectors (Dong et al. 2014; Poppe et al. 2015; Raffaele et al. 2010; Sharma et al. 2014). Organ-specific infection as well as different stages during infection in a host also requires distinctive sets of effectors (Schilling et al. 2014; Skibbe et al. 2010; Wang et al. 2011). Effector family and family size are also significantly different among the pathogens with different lifestyles (Baxter et al. 2010; Kämper et al. 2006; Lévesque et al. 2010; Spanu et al. 2010). In addition to gain and loss of gene copies, effector genes display highly specialized expression plasticity. Typical effectors exhibit highly host-induced and stage-specific gene expression patterns, but a large number $(>50 \%)$ of predicted effector genes may actually be pseudogenes (Dong et al. 2012; Haas et al. 2009; Shen et al. 2013; Wang et al. 2011), suggesting that the number of effector genes that are employed by the pathogen for infection are likely overestimated and that 
complex patterns of effector gain and loss characterize pathogen evolution. Diversity in the mechanisms of gene expression regulation in different organisms may also be responsible for the plasticity of effector repertoires (Qutob et al. 2013; Soyer et al. 2014; Wang et al. 2011). Further high-throughput identification, deep functional analyses, and comparative genomic studies of effector repertoires in various pathogens will help to comprehensively and systematically investigate the biological roles and networks of effectors in pathogen-plant interactions and address the question of why different pathogens evolved to use different kinds and numbers of effectors.

\section{Question 9: How do pathogens evolve novel virulence activities?}

The pathogen landscape is constantly changing. New pathogens appear and existing ones become more virulent. Sometimes, a well-known pathogen will jump to a new host. How do microbes acquire new virulence activities? What are the genetic and ecological conditions needed for the appearance of new pathogens or new pathogen hosts? What are the costs?

Genomics has uncovered multiple mechanisms for pathogens to rapidly adapt to changing host populations (Frantzeskakis et al. 2020). We are still discovering new pathogen effectors (Djavaheri et al. 2019; Martínez-Cruz et al. 2018), and there is much to be learned about the in-planta functions of known effectors (Büttner 2016; Li and Day 2019). Pathogen effectors are not limited to proteins; small RNAs may also be effectors with host gene targets (Derbyshire et al. 2019; Weiberg et al. 2013). Horizontal gene transfer combines with genome flexibility to provide the genetic variation needed to acquire new virulence functions via recombination or gene duplication and neofunctionalization or via horizontal transfer of genes or chromosomes (Bertazzoni et al. 2018; Fouché et al. 2018; Tanaka et al. 2019).

What is the relative role of novel genes versus mutation of existing genes in maintaining virulence and generating new virulence traits? What are the host targets of pathogen gene products in plants and how do the targets constrain or select for novel variants in pathogens? Continuing discoveries regarding the molecular interactions between host and pathogen gene products will improve our understanding of the evolution of virulence in plant pathogens.

\section{Question 10: How do observations of binary plant- microbe interactions hold in an ecological context?}

While plant-microbe interactions have historically been studied at the molecular level in pairwise interactions, questions 1 and 4 demonstrate the dawning realization of the importance of the multitude of biotic interactions that plants and microbes face simultaneously. There are numerous examples of disconnects between disease phenotypes of plant-pathogen interactions observed in the lab and in the field that are explained by differences in the "environment" component of the disease triangle, which includes biotic interactions as well as abiotic effects on plants and microbes. In the field, multiple infections are the rule, not the exception, and diseases such as maize lethal necrosis, caused by simultaneous infection with two viruses that show a multiplicative effect on disease severity, highlight the potential impact of multiple infections (Redinbaugh and Stewart 2018). Similarly, microbial communities can mediate pathogenic interactions in the field (Schlatter et al. 2017). Furthermore, community ecology shows that outcomes of multispecies interactions are not intuitive; rather, they depend on species composition, their functions in the community, and their order of arrival (e.g., which hosts and pathogens are present, how they interact, and which pathogens colonized which hosts first).

At the molecular level, researchers have demonstrated crosstalk in plant defenses that affects plant-microbe interactions and also observes a priority effect, meaning that the outcome of infection can depend on who infects first (Prince et al. 2017). There is also increasing evidence of interactions between plant defense and abiotic conditions, which can be mediated by the plant community (discussed in question 2 ). For example, in a resourcelimited environment, the presence of a competitor may create nutrient or water limitation that affects interactions with microbes. In addition, redundancy in host targets among effectors may contribute to unexpected outcomes of multiple infection that may not be apparent when genes or alleles are considered to be specific to pairwise interactions.

These few examples provide only a glimpse at the many factors that shape the complexity of the biotic environments that drive plant growth, development, and the exponentially large number of interactions they encounter during their lifecycle. What remains are the unknown mechanisms that are so essential yet remain largely undefined. Thus, our lack of a full understanding makes it difficult to precisely predict the ways in which plants and microbes will interact when in the presence of entire communities of microbes, animals, and other plants. A more nuanced understanding of the way in which a plant and microbe interact, based on the biotic and abiotic environment in which they find themselves, is essential to understanding how these interactions promote plant health or disease. An improved understanding of how a particular plant and microbe interact within an ecological context has important implications for agriculture, management of invasive species, and conservation.

\section{CONCLUSION}

The quest to identify the big, unanswered questions in molecular plant-microbe interactions, initiated by the MPMI editorial board, resulted in a list of ten, broad-reaching, fundamental questions that influence and inform our research. This list of questions helps crystallize some of the big issues facing the field of MPMI, framing them in a way that draws different research areas together. Building this list with the help of discussions and ideas from a community of researchers drawn from 52 different countries also means that this list of questions is spreading world-wide.

As the conversation expands, our connections as a research community strengthen and ideas and experiments will start to ripple back, enriching our science and our community. MPMI is excited to be the nexus for this discussion. Expect a series of reviews and perspectives in MPMI that address each of these Top 10 questions in the coming months. We hope that this list of the Top 10 questions will also encourage young scientists who are finding their path through this field to reach toward these goals and help us as we try to answer the unknown. $M P M I$ welcomes papers that address these fundamental questions, and we look forward to an excellent discussion, both in the pages of the journal and via conversation in our Microgreens podcast, on all these topics.

In addition to the value of identifying the Top 10 unanswered questions in $M P M I$, the process of working together, as a community, to define these questions, was valuable in itself, and the engagement of the community in the search for the Top 10 added an extra intellectual dimension to the excellent science being presented and discussed at the IC-MPMI. What will happen next? The effect of the Top 10 list on the community is another unknown. Will it drive people to focus their research on these big issues? We look forward to an exciting time of reading about new advances addressing these core questions.

\section{ACKNOWLEDGMENTS}

We are grateful for the support of IS-MPMI and, in particular, R. Kahmann, IS-MPMI president, and the local organizing committee for the 2019 
congress, especially P. Birch and J. Jones. We also thank the APS staff, especially G. Grahek and A. Carlin for their encouragement and for hours of technical support for running this Top10 MPMI project at the IC-MPMI congress and J. McDowell for thoughtful comments on the manuscript.

\section{AUTHOR-RECOMMENDED INTERNET RESOURCE}

Microgreens podcast: http://microgreens.buzzsprout.com/

\section{LITERATURE CITED}

Ai, G., Yang, K., Ye, W., Tian, Y., Du, Y., Zhu, H., Li, T., Xia, Q., Shen, D., Peng, H., Jing, M., Xia, A., and Dou, D. 2020. Prediction and characterization of RXLR effectors in Pythium species. Mol. PlantMicrobe Interact. 33:1046-1058.

Baggs, E. L., Monroe, J. G., Thanki, A. S., O’Grady, R., Schudoma, C. Haerty, W., and Krasileva, K. V. 2020. Convergent loss of an EDS1/PAD4 signaling pathway in several plant lineages reveals coevolved components of plant immunity and drought response. Plant Cell 32:2158-2177.

Balint-Kurti, P. 2019. The plant hypersensitive response: Concepts, control and consequences. Mol. Plant Pathol. 20:1163-1178.

Baltrus, D. A., Nishimura, M. T., Romanchuk, A., Chang, J. H., Mukhtar, M. S., Cherkis, K., Roach, J., Grant, S. R., Jones, C. D., and Dangl, J. L. 2011. Dynamic evolution of pathogenicity revealed by sequencing and comparative genomics of 19 Pseudomonas syringae isolates. PLoS Pathog. 7:e1002132.

Baxter, L., Tripathy, S., Ishaque, N., Boot, N., Cabral, A., Kemen, E., Thines, M., Ah-Fong, A., Anderson, R., Badejoko, W., Bittner-Eddy, P., Boore, J. L., Chibucos, M. C., Coates, M., Dehal, P., Delehaunty, K., Dong, S., Downton, P., Dumas, B., Fabro, G., Fronick, C., Fuerstenberg, S. I., Fulton, L., Gaulin, E., Govers, F., Hughes, L., Humphray, S., Jiang, R. H. Y., Judelson, H., Kamoun, S., Kyung, K., Meijer, H., Minx, P., Morris, P., Nelson, J., Phuntumart, V., Qutob, D., Rehmany, A., RougonCardoso, A., Ryden, P., Torto-Alalibo, T., Studholme, D., Wang, Y., Win, J., Wood, J., Clifton, S. W., Rogers, J., Van den Ackerveken, G., Jones, J. D. G., McDowell, J. M., Beynon, J., and Tyler, B. M. 2010. Signatures of adaptation to obligate biotrophy in the Hyaloperonospora arabidopsidis genome. Science 330:1549-1551.

Berens, M. L., Wolinska, K. W., Spaepen, S., Ziegler, J., Nobori, T., Nair, A., Krüler, V., Winkelmüller, T. M., Wang, Y., Mine, A., Becker, D., Garrido-Oter, R., Schulze-Lefert, P., and Tsuda, K. 2019. Balancing trade-offs between biotic and abiotic stress responses through leaf agedependent variation in stress hormone cross-talk. Proc. Natl. Acad. Sci. U.S.A. 116:2364-2373.

Berrabah, F., Ratet, P., and Gourion, B. 2019. Legume nodules: Massive infection in the absence of defense induction. Mol. Plant-Microbe Interact. 32:35-44.

Bertazzoni, S., Williams, A. H., Jones, D. A., Syme, R. A., Tan, K. C., and Hane, J. K. 2018. Accessories make the outfit: Accessory chromosomes and other dispensable DNA regions in plant-pathogenic fungi. Mol. Plant-Microbe Interact. 31:779-788.

Białas, A., Zess, E. K., De la Concepcion, J. C., Franceschetti, M., Pennington, H. G., Yoshida, K., Upson, J. L., Chanclud, E., Wu, C. H., Langner, T., Maqbool, A., Varden, F. A., Derevnina, L., Belhaj, K., Fujisaki, K., Saitoh, H., Terauchi, R., Banfield, M. J., and Kamoun, S. 2018. Lessons in effector and NLR biology of plant-microbe systems. Mol. Plant-Microbe Interact. 31:34-45.

Boutemy, L. S., King, S. R., Win, J., Hughes, R. K., Clarke, T. A., Blumenschein, T. M., Kamoun, S., and Banfield, M. J. 2011. Structures of Phytophthora RXLR effector proteins: A conserved but adaptable fold underpins functional diversity. J. Biol. Chem. 286:35834-35842.

Büttner, D. 2016. Behind the lines-actions of bacterial type III effector proteins in plant cells. FEMS Microbiol. Rev. 40:894-937.

Chae, E., Bomblies, K., Kim, S. T., Karelina, D., Zaidem, M., Ossowski, S., Martín-Pizarro, C., Laitinen, R. A., Rowan, B. A., Tenenboim, H., Lechner, S., Demar, M., Habring-Müller, A., Lanz, C., Rätsch, G., and Weigel, D. 2014. Species-wide genetic incompatibility analysis identifies immune genes as hot spots of deleterious epistasis. Cell 159:1341-1351.

Chintamanani, S., Hulbert, S. H., Johal, G. S., and Balint-Kurti, P. J. 2010 Identification of a maize locus that modulates the hypersensitive defense response, using mutant-assisted gene identification and characterization. Genetics 184:813-825.

Conrath, U., Beckers, G. J., Flors, V., García-Agustín, P., Jakab, G., Mauch, F., Newman, M. A., Pieterse, C. M., Poinssot, B., Pozo, M. J., Pugin, A., Schaffrath, U., Ton, J., Wendehenne, D., Zimmerli, L., and Mauch-Mani, B.; Prime-A-Plant Group. 2006. Priming: Getting ready for battle. Mol. Plant-Microbe Interact. 19:1062-1071.
Costa, S. R., Chin, S., and Mathesius, U. 2020. Infection of Medicago truncatula by the root-knot nematode Meloidogyne javanica does not require early nodulation genes. Front. Plant Sci. 11:1050.

Couch, B. C., Fudal, I., LeBrun, M.-H., Tharreau, D., Valent, B., van Kim, P., Nottégham, J.-L., and Kohn, L. M. 2005. Origins of host-specific populations of the blast pathogen Magnaporthe oryzae in crop domestication with subsequent expansion of pandemic clones on rice and weeds of rice. Genetics 170:613-630.

de Wit, P. J. 2016. Cladosporium fulvum effectors: Weapons in the arms race with tomato. Annu. Rev. Phytopathol. 54:1-23.

Deng, W., Marshall, N. C., Rowland, J. L., McCoy, J. M., Worrall, L. J., Santos, A. S., Strynadka, N. C. J., and Finlay, B. B. 2017. Assembly, structure, function and regulation of type III secretion systems. Nat. Rev. Microbiol. 15:323-337.

Derbyshire, M., Mbengue, M., Barascud, M., Navaud, O., and Raffaele, S. 2019. Small RNAs from the plant pathogenic fungus Sclerotinia sclerotiorum highlight host candidate genes associated with quantitative disease resistance. Mol. Plant Pathol. 20:1279-1297.

Deutsch, C. A., Tewksbury, J. J., Tigchelaar, M., Battisti, D. S., Merrill, S. C., Huey, R. B., and Naylor, R. L. 2018. Increase in crop losses to insect pests in a warming climate. Science 361:916-919.

Dillon, M. M., Almeida, R. N. D., Laflamme, B., Martel, A., Weir, B. S., Desveaux, D., and Guttman, D. S. 2019. Molecular evolution of Pseudomonas syringae type III secreted effector proteins. Front. Plant Sci. 10:418.

Djavaheri, M., Ma, L., Klessig, D. F., Mithöfer, A., Gropp, G., and Borhan, H. 2019. Mimicking the Host Regulation of salicylic acid: A virulence strategy by the clubroot pathogen Plasmodiophora brassicae. Mol. Plant-Microbe Interact. 32:296-305.

Dong, S., Kong, G., Qutob, D., Yu, X., Tang, J., Kang, J., Dai, T., Wang, H., Gijzen, M., and Wang, Y. 2012. The NLP toxin family in Phytophthora sojae includes rapidly evolving groups that lack necrosis-inducing activity. Mol. Plant-Microbe Interact. 25:896-909.

Dong, S., Raffaele, S., and Kamoun, S. 2015a. The two-speed genomes of filamentous pathogens: Waltz with plants. Curr. Opin. Genet. Dev. 35:57-65.

Dong, S., Stam, R., Cano, L. M., Song, J., Sklenar, J., Yoshida, K., Bozkurt, T. O., Oliva, R., Liu, Z., Tian, M., Win, J., Banfield, M. J., Jones, A. M., van der Hoorn, R. A., and Kamoun, S. 2014. Effector specialization in a lineage of the Irish potato famine pathogen. Science 343:552-555

Dong, Y., Li, Y., Zhao, M., Jing, M., Liu, X., Liu, M., Guo, X., Zhang, X., Chen, Y., Liu, Y., Liu, Y., Ye, W., Zhang, H., Wang, Y., Zheng, X., Wang, P., and Zhang, Z. 2015b. Global genome and transcriptome analyses of Magnaporthe oryzae epidemic isolate 98-06 uncover novel effectors and pathogenicity-related genes, revealing gene gain and lose dynamics in genome evolution. PLoS Pathog. 11:e1004801.

Evelin, H., Devi, T. S., Gupta, S., and Kapoor, R. 2019. Mitigation of salinity stress in plants by arbuscular mycorrhizal symbiosis: Current understanding and new challenges. Front. Plant Sci. 10:470.

Faino, L., Seidl, M. F., Shi-Kunne, X., Pauper, M., van den Berg, G. C., Wittenberg, A. H., and Thomma, B. P. 2016. Transposons passively and actively contribute to evolution of the two-speed genome of a fungal pathogen. Genome Res. 26:1091-1100.

Field, K. J., and Pressel, S. 2018. Unity in diversity: Structural and functional insights into the ancient partnerships between plants and fungi. New Phytol. 220:996-1011.

Fitton, N., Alexander, P., Arnell, N., Bajzelj, B., Calvin, K., Doelman, J., Gerber, J. S., Havlik, P., Hasegawa, T., Herrero, M., Krisztin, T., van Meijl, H., Powell, T., Sands, R., Stehfest, E., West, P. C., and Smith, P. 2019. The vulnerabilities of agricultural land and food production to future water scarcity. Glob. Environ. Change 58:101944.

Fouché, S., Plissonneau, C., and Croll, D. 2018. The birth and death of effectors in rapidly evolving filamentous pathogen genomes. Curr. Opin. Microbiol. 46:34-42.

Frantzeskakis, L., Di Pietro, A., Rep, M., Schirawski, J., Wu, C. H., and Panstruga, R. 2020. Rapid evolution in plant-microbe interactions - a molecular genomics perspective. New Phytol. 225:1134-1142.

Friesen, T. L., Stukenbrock, E. H., Liu, Z., Meinhardt, S., Ling, H., Faris, J. D., Rasmussen, J. B., Solomon, P. S., McDonald, B. A., and Oliver, R. P. 2006. Emergence of a new disease as a result of interspecific virulence gene transfer. Nat. Genet. 38:953-956.

Gao, M., Glenn, A. E., Gu, X., Mitchell, T. R., Satterlee, T., Duke, M. V., Scheffler, B. E., and Gold, S. E. 2020. Pyrrocidine, a molecular off switch for fumonisin biosynthesis. PLoS Pathog. 16:e1008595.

Haas, B. J., Kamoun, S., Zody, M. C., Jiang, R. H., Handsaker, R. E., Cano, L. M., Grabherr, M., Kodira, C. D., Raffaele, S., Torto-Alalibo, T., Bozkurt, T. O., Ah-Fong, A. M., Alvarado, L., Anderson, V. L. Armstrong, M. R., Avrova, A., Baxter, L., Beynon, J., Boevink, P. C., Bollmann, S. R., Bos, J. I., Bulone, V., Cai, G., Cakir, C., Carrington, 
J. C., Chawner, M., Conti, L., Costanzo, S., Ewan, R., Fahlgren, N., Fischbach, M. A., Fugelstad, J., Gilroy, E. M., Gnerre, S., Green, P. J., Grenville-Briggs, L. J., Griffith, J., Grünwald, N. J., Horn, K., Horner, N. R., Hu, C. H., Huitema, E., Jeong, D. H., Jones, A. M., Jones, J. D., Jones, R. W., Karlsson, E. K., Kunjeti, S. G., Lamour, K., Liu, Z., Ma, L., Maclean, D., Chibucos, M. C., McDonald, H., McWalters, J., Meijer, H. J., Morgan, W., Morris, P. F., Munro, C. A., O’Neill, K., OspinaGiraldo, M., Pinzón, A., Pritchard, L., Ramsahoye, B., Ren, Q., Restrepo, S., Roy, S., Sadanandom, A., Savidor, A., Schornack, S., Schwartz, D. C., Schumann, U. D., Schwessinger, B., Seyer, L., Sharpe, T., Silvar, C., Song, J., Studholme, D. J., Sykes, S., Thines, M., van de Vondervoort, P. J., Phuntumart, V., Wawra, S., Weide, R., Win, J., Young, C., Zhou, S., Fry, W., Meyers, B. C., van West, P., Ristaino, J., Govers, F., Birch, P. R., Whisson, S. C., Judelson, H. S., and Nusbaum, C. 2009. Genome sequence and analysis of the Irish potato famine pathogen Phytophthora infestans. Nature 461:393-398.

Hartmann, F. E., Sánchez-Vallet, A., McDonald, B. A., and Croll, D. 2017. A fungal wheat pathogen evolved host specialization by extensive chromosomal rearrangements. ISME J. 11:1189-1204.

Hassani, M. A., Durán, P., and Hacquard, S. 2018. Microbial interactions within the plant holobiont. Microbiome 6:58.

He, J., Ye, W., Choi, D. S., Wu, B., Zhai, Y., Guo, B., Duan, S., Wang, Y., Gan, J., Ma, W., and Ma, J. 2019. Structural analysis of Phytophthora suppressor of RNA silencing 2 (PSR2) reveals a conserved modular fold contributing to virulence. Proc. Natl. Acad. Sci. U.S.A. 116: 8054-8059.

Heath, M. C. 1985. Implications of Nonhost Resistance for Understanding Host-Parasite Interactions. Pages 25-42 in: Genetic Basis of Biochemical Mechanisms of Plant Disease. J. V. Groth and W. R. Bushnell, eds. APS Press, St. Paul MN, U.S.A.

Hubert, D. A., He, Y., McNulty, B. C., Tornero, P., and Dangl, J. L. 2009. Specific Arabidopsis HSP90.2 alleles recapitulate RAR1 cochaperone function in plant NB-LRR disease resistance protein regulation. Proc. Natl. Acad. Sci. U.S.A. 106:9556-9563.

Inuma, T., Khodaparast, S. E., and Takamatsu, S. 2007. Multilocus phylogenetic analyses within Blumeria graminis, a powdery mildew fungus of cereals. Mol. Phylogenet. Evol. 44:741-751.

Jiang, R. H., Tripathy, S., Govers, F., and Tyler, B. M. 2008. RXLR effector reservoir in two Phytophthora species is dominated by a single rapidly evolving superfamily with more than 700 members. Proc. Natl. Acad. Sci. U.S.A. 105:4874-4879.

Jiang, R. H., and Tyler, B. M. 2012. Mechanisms and evolution of virulence in oomycetes. Annu. Rev. Phytopathol. 50:295-318.

Joardar, V., Lindeberg, M., Schneider, D. J., Collmer, A., and Buell, C. R. 2005. Lineage-specific regions in Pseudomonas syringae pv tomato DC3000. Mol. Plant Pathol. 6:53-64.

Johnson, D. A., Cummings, T. F., Ghanem, R. A., and Alldredge, J. R. 2009. Association of Solar Irradiance and Days of Precipitation with Incidence of Potato Late Blight in the Semiarid Environment of the Columbia Basin. Plant Dis. 93:272-280.

Jones, J. D., and Dangl, J. L. 2006. The plant immune system. Nature 444: 323-329.

Kämper, J., Kahmann, R., Bölker, M., Ma, L. J., Brefort, T., Saville, B. J., Banuett, F., Kronstad, J. W., Gold, S. E., Müller, O., Perlin, M. H., Wösten, H. A., de Vries, R., Ruiz-Herrera, J., Reynaga-Peña, C. G., Snetselaar, K., McCann, M., Pérez-Martín, J., Feldbrügge, M., Basse, C. W., Steinberg, G., Ibeas, J. I., Holloman, W., Guzman, P., Farman, M., Stajich, J. E., Sentandreu, R., González-Prieto, J. M., Kennell, J. C., Molina, L., Schirawski, J., Mendoza-Mendoza, A., Greilinger, D., Münch, K., Rössel, N., Scherer, M., Vranes, M., Ladendorf, O., Vincon, V., Fuchs, U., Sandrock, B., Meng, S., Ho, E. C., Cahill, M. J., Boyce, K. J., Klose, J., Klosterman, S. J., Deelstra, H. J., Ortiz-Castellanos, L., Li, W., Sanchez-Alonso, P., Schreier, P. H., Häuser-Hahn, I., Vaupel, M., Koopmann, E., Friedrich, G., Voss, H., Schlüter, T., Margolis, J., Platt, D., Swimmer, C., Gnirke, A., Chen, F., Vysotskaia, V., Mannhaupt, G., Güldener, U., Münsterkötter, M., Haase, D., Oesterheld, M., Mewes, H. W., Mauceli, E. W., DeCaprio, D., Wade, C. M., Butler, J., Young, S., Jaffe, D. B., Calvo, S., Nusbaum, C., Galagan, J., and Birren, B. W. 2006. Insights from the genome of the biotrophic fungal plant pathogen Ustilago maydis. Nature 444:97-101.

Khan, M., Seto, D., Subramaniam, R., and Desveaux, D. 2018. Oh, the places they'll go! A survey of phytopathogen effectors and their host targets. Plant J. 93:651-663.

Kivlin, S. N., Emery, S. M., and Rudgers, J. A. 2013. Fungal symbionts alter plant responses to global change. Am. J. Bot. 100:1445-1457.

Kourelis, J., and van der Hoorn, R. A. L. 2018. Defended to the Nines: 25 years of resistance gene cloning identifies nine mechanisms for $\mathrm{R}$ protein function. Plant Cell 30:285-299.
Laflamme, B., Dillon, M. M., Martel, A., Almeida, R. N. D., Desveaux, D., and Guttman, D. S. 2020. The pan-genome effector-triggered immunity landscape of a host-pathogen interaction. Science 367:763-768.

Lévesque, C. A., Brouwer, H., Cano, L., Hamilton, J. P., Holt, C., Huitema, E., Raffaele, S., Robideau, G. P., Thines, M., Win, J., Zerillo, M. M., Beakes, G. W., Boore, J. L., Busam, D., Dumas, B., Ferriera, S., Fuerstenberg, S. I., Gachon, C. M., Gaulin, E., Govers, F., GrenvilleBriggs, L., Horner, N., Hostetler, J., Jiang, R. H., Johnson, J., Krajaejun, T., Lin, H., Meijer, H. J., Moore, B., Morris, P., Phuntmart, V., Puiu, D., Shetty, J., Stajich, J. E., Tripathy, S., Wawra, S., van West, P., Whitty, B. R., Coutinho, P. M., Henrissat, B., Martin, F., Thomas, P. D., Tyler, B. M., De Vries, R. P., Kamoun, S., Yandell, M., Tisserat, N., and Buell, C. R. 2010. Genome sequence of the necrotrophic plant pathogen Pythium ultimum reveals original pathogenicity mechanisms and effector repertoire. Genome Biol. 11:R73.

Li, P., and Day, B. 2019. Battlefield cytoskeleton: Turning the tide on plant immunity. Mol. Plant-Microbe Interact. 32:25-34.

Liang, Y., Cao, Y., Tanaka, K., Thibivilliers, S., Wan, J., Choi, J., Kang, Ch., Qiu, J., and Stacey, G. 2013. Nonlegumes respond to rhizobial Nod factors by suppressing the innate immune response. Science 341: 1384-1387.

Lipka, U., Fuchs, R., and Lipka, V. 2008. Arabidopsis non-host resistance to powdery mildews. Curr. Opin. Plant Biol. 11:404-411.

Lo Presti, L., Lanver, D., Schweizer, G., Tanaka, S., Liang, L., Tollot, M., Zuccaro, A., Reissmann, S., and Kahmann, R. 2015. Fungal effectors and plant susceptibility. Annu. Rev. Plant Biol. 66:513-545.

Lorang, J. M. 2019. Necrotrophic exploitation and subversion of plant defense: A lifestyle or just a phase, and implications in breeding resistance. Phytopathology 109:332-346.

Ma, L., and Borhan, M. H. 2015. The receptor-like kinase SOBIR1 interacts with Brassica napus LepR3 and is required for Leptosphaeria maculans AvrLm1-triggered immunity. Front. Plant Sci. 6:933.

Ma, L. J., van der Does, H. C., Borkovich, K. A., Coleman, J. J., Daboussi, M. J., Di Pietro, A., Dufresne, M., Freitag, M., Grabherr, M., Henrissat, B., Houterman, P. M., Kang, S., Shim, W. B., Woloshuk, C., Xie, X., Xu, J. R., Antoniw, J., Baker, S. E., Bluhm, B. H., Breakspear, A., Brown, D. W., Butchko, R. A., Chapman, S., Coulson, R., Coutinho, P. M., Danchin, E. G., Diener, A., Gale, L. R., Gardiner, D. M., Goff, S., Hammond-Kosack, K. E., Hilburn, K., Hua-Van, A., Jonkers, W., Kazan, K., Kodira, C. D., Koehrsen, M., Kumar, L., Lee, Y. H., Li, L., Manners, J. M., Miranda-Saavedra, D., Mukherjee, M., Park, G., Park, J., Park, S. Y., Proctor, R. H., Regev, A., Ruiz-Roldan, M. C., Sain, D., Sakthikumar, S., Sykes, S., Schwartz, D. C., Turgeon, B. G., Wapinski, I., Yoder, O., Young, S., Zeng, Q., Zhou, S., Galagan, J., Cuomo, C. A., Kistler, H. C., and Rep, M. 2010. Comparative genomics reveals mobile pathogenicity chromosomes in Fusarium. Nature 464:367-373.

Marquez, L. M., Redman, R. S., Rodriguez, R. J., and Roossinck, M. J. 2007. A virus in a fungus in a plant: Three-way symbiosis required for thermal tolerance. Science 315:513-515.

Martínez-Cruz, J., Romero, D., de la Torre, F. N., Fernández-Ortuño, D., Torés, J. A., de Vicente, A., and Pérez-García, A. 2018. The functional characterization of Podosphaera xanthii candidate effector genes reveals novel target functions for fungal pathogenicity. Mol. Plant-Microbe Interact. 31:914-931.

Martinez Henao, J., Demers, L. E., Grosser, K., Schedl, A., van Dam, N. M., and Bede, J. C. 2020. Fertilizer rate-associated increase in foliar jasmonate burst observed in wounded Arabidopsis thaliana leaves is attenuated at $\mathrm{eCO}_{2}$. Front. Plant Sci. 10:1636.

Mhamdi, A., and Noctor, G. 2016. High $\mathrm{CO}_{2}$ primes plant biotic stress defences through redox-linked pathways. Plant Physiol. 172:929-942.

Möller, M., and Stukenbrock, E. H. 2017. Evolution and genome architecture in fungal plant pathogens. Nat. Rev. Microbiol. 15:756-771.

Naum, M., Brown, E. W., and Mason-Gamer, R. J. 2009. Phylogenetic evidence for extensive horizontal gene transfer of type III secretion system genes among enterobacterial plant pathogens. Microbiology 155: 3187-3199.

Ngou, B. P. M., Ahn, H.-K., Ding, P., and Jones, J. D. G. 2020. Mutual potentiation of plant immunity by cell-surface and intracellular receptors. bioRxiv. doi.org/10.1101/2020.04.10.034173.

Panagos, P., Standardi, G., Borrelli, P., Lugato, E., Montanarella, L., and Bosello, F. 2018. Cost of agricultural productivity loss due to soil erosion in the European Union: From direct cost evaluation approaches to the use of macroeconomic models. Land Degrad. Dev. 29: 471-484.

Panstruga, R. 2003. Establishing compatibility between plants and obligate biotrophic pathogens. Curr. Opin. Plant Biol. 6:320-326.

Panstruga, R., and Moscou, M. J. 2020. What is the molecular basis of nonhost resistance? Mol. Plant-Microbe Interact. 31:1253-1264. 
Peng, Y., van Wersch, R., and Zhang, Y. 2018. Convergent and divergent signaling in PAMP-triggered immunity and effector-triggered immunity. Mol. Plant-Microbe Interact. 31:403-409.

Pieterse, C. M., Zamioudis, C., Berendsen, R. L., Weller, D. M., Van Wees, S. C., and Bakker, P. A. 2014. Induced systemic resistance by beneficial microbes. Annu. Rev. Phytopathol. 52:347-375.

Poppe, S., Dorsheimer, L., Happel, P., and Stukenbrock, E. H. 2015. Rapidly evolving genes are key players in host specialization and virulence of the fungal wheat pathogen Zymoseptoria tritici (Mycosphaerella graminicola). PLoS Pathog. 11:e1005055.

Postma, J., Liebrand, T. W. H., Bi, G., Evrard, A., Bye, R. R., Mbengue, M., Kuhn, H., Joosten, M. H. A. J., and Robatzek, S. 2016. Avr4 promotes Cf-4 receptor-like protein association with the BAK1/SERK3 receptorlike kinase to initiate receptor endocytosis and plant immunity. New Phytol. 210:627-642.

Prince, D. C., Rallapalli, G., Xu, D., Schoonbeek, H. J., Çevik, V., Asai, S., Kemen, E., Cruz-Mireles, N., Kemen, A., Belhaj, K., Schornack, S., Kamoun, S., Holub, E. B., Halkier, B. A., and Jones, J. D. G. 2017 Albugo-imposed changes to tryptophan-derived antimicrobial metabolite biosynthesis may contribute to suppression of non-host resistance to Phytophthora infestans in Arabidopsis thaliana. BMC Biol. 15:20.

Qutob, D., Chapman, B. P., and Gijzen, M. 2013. Transgenerational gene silencing causes gain of virulence in a plant pathogen. Nat. Commun. 4: 1349.

Raffaele, S., Farrer, R. A., Cano, L. M., Studholme, D. J., MacLean, D., Thines, M., Jiang, R. H., Zody, M. C., Kunjeti, S. G., Donofrio, N. M., Meyers, B. C., Nusbaum, C., and Kamoun, S. 2010. Genome evolution following host jumps in the Irish potato famine pathogen lineage. Science 330:1540-1543.

Ranf, S. 2017. Sensing of molecular patterns through cell surface immune receptors. Curr. Opin. Plant Biol. 38:68-77.

Redinbaugh, M. G., and Stewart, L. R. 2018. Maize lethal necrosis: An emerging, synergistic viral disease. Annu. Rev. Virol. 5:301-322.

Rodriguez, P. A., Rothballer, M., Chowdhury, S. P., Nussbaumer, T., Gutjahr, C., and Falter-Braun, P. 2019. Systems biology of plantmicrobiome interactions. Mol. Plant 12:804-821.

Rojas-Estevez, P., Urbina-Gómez, D. A., Ayala-Usma, D. A., GuayazanPalacios, N., Mideros, M. F., Bernal, A. J., Cardenas, M., and Restrepo, S. 2020. Effector repertoire of Phytophthora betacei: In search of possible virulence factors responsible for its host specificity. Front. Genet. 11:579.

Savory, F., Leonard, G., and Richards, T. A. 2015. The role of horizontal gene transfer in the evolution of the oomycetes. PLoS Pathog. 11:e1004805.

Schilling, L., Matei, A., Redkar, A., Walbot, V., and Doehlemann, G. 2014. Virulence of the maize smut Ustilago maydis is shaped by organ-specific effectors. Mol. Plant Pathol. 15:780-789.

Schlatter, D., Kinkel, L., Thomashow, L., Weller, D., and Paulitz, T. 2017. Disease suppressive soils: New insights from the soil microbiome. Phytopathology 107:1284-1297.

Sharma, R., Mishra, B., Runge, F., and Thines, M. 2014. Gene loss rather than gene gain is associated with a host jump from monocots to dicots in the Smut Fungus Melanopsichium pennsylvanicum. Genome Biol. Evol. 6:2034-2049.

Shaul, O., Galili, S., Volpin, H., Ginzberg, I., Elad, Y., Chet, I., and Kapulnik, Y. 1999. Mycorrhiza-induced changes in disease severity and PR protein expression in tobacco leaves. Mol. Plant-Microbe Interact. 12:1000-1007.

Shen, D., Liu, T., Ye, W., Liu, L., Liu, P., Wu, Y., Wang, Y., and Dou, D. 2013. Gene duplication and fragment recombination drive functional diversification of a superfamily of cytoplasmic effectors in Phytophthora sojae. PLoS One 8:e70036.

Sherwood, S., and Fu, Q. 2014. Climate change. A drier future? Science 343:737-739.

Skibbe, D. S., Doehlemann, G., Fernandes, J., and Walbot, V. 2010. Maize tumors caused by Ustilago maydis require organ-specific genes in host and pathogen. Science 328:89-92.
Smigielski, L., Laubach, E. M., Pesch, L., Glock, J. M. L., Albrecht, F., Slusarenko, A., Panstruga, R., and Kuhn, H. 2019. Nodulation induces systemic resistance of Medicago truncatula and Pisum sativum against Erysiphe pisi and primes for powdery mildew-triggered salicylic acid accumulation. Mol. Plant-Microbe Interact. 32:1243-1255.

Soyer, J. L., El Ghalid, M., Glaser, N., Ollivier, B., Linglin, J., Grandaubert, J., Balesdent, M. H., Connolly, L. R., Freitag, M., Rouxel, T., and Fudal, I. 2014. Epigenetic control of effector gene expression in the plant pathogenic fungus Leptosphaeria maculans. PLoS Genet. 10:e1004227.

Spanu, P. D., Abbott, J. C., Amselem, J., Burgis, T. A., Soanes, D. M., Stüber, K., Ver Loren van Themaat, E., Brown, J. K., Butcher, S. A., Gurr, S. J., Lebrun, M. H., Ridout, C. J., Schulze-Lefert, P., Talbot, N. J., Ahmadinejad, N., Ametz, C., Barton, G. R., Benjdia, M., Bidzinski, P., Bindschedler, L. V., Both, M., Brewer, M. T., Cadle-Davidson, L., CadleDavidson, M. M., Collemare, J., Cramer, R., Frenkel, O., Godfrey, D., Harriman, J., Hoede, C., King, B. C., Klages, S., Kleemann, J., Knoll, D., Koti, P. S., Kreplak, J., López-Ruiz, F. J., Lu, X., Maekawa, T., Mahanil, S., Micali, C., Milgroom, M. G., Montana, G., Noir, S., O’Connell, R. J., Oberhaensli, S., Parlange, F., Pedersen, C., Quesneville, H., Reinhardt, R., Rott, M., Sacristán, S., Schmidt, S. M., Schön, M., Skamnioti, P. Sommer, H., Stephens, A., Takahara, H., Thordal-Christensen, H., Vigouroux, M., Wessling, R., Wicker, T., and Panstruga, R. 2010. Genome expansion and gene loss in powdery mildew fungi reveal tradeoffs in extreme parasitism. Science 330:1543-1546.

Sun, J., Cardoza, V., Mitchell, D. M., Bright, L., Oldroyd, G., and Harris, J. M. 2006. Crosstalk between jasmonic acid, ethylene and Nod factor signaling allows integration of diverse inputs for regulation of nodulation. Plant J. 46:961-970.

Sun, Y., Zhu, Y.-X., Balint-Kurti, P. J., and Wang, G.-F. 2020. Fine-tuning immunity: Players and regulators for plant NLRs. Trends Plant Sci. 25: 695-713.

Tanaka, S., Schweizer, G., Rössel, N., Fukada, F., Thines, M., and Kahmann, R. 2019. Neofunctionalization of the secreted Tin2 effector in the fungal pathogen Ustilago maydis. Nat. Microbiol. 4:251-257.

Thordal-Christensen, H. 2003. Fresh insights into processes of nonhost resistance. Curr. Opin. Plant Biol. 6:351-357.

Wang, G.-F., and Balint-Kurti, P. J. 2015. Cytoplasmic and nuclear localizations are important for the hypersensitive response conferred by maize autoactive Rp1-D21 protein. Mol. Plant-Microbe Interact. 28:1023-1031.

Wang, J., Hu, M., Wang, J., Qi, J., Han, Z., Wang, G., Qi, Y., Wang, H. W., Zhou, J. M., and Chai, J. 2019. Reconstitution and structure of a plant NLR resistosome conferring immunity. Science 364:eaav5870.

Wang, Q., Han, C., Ferreira, A. O., Yu, X., Ye, W., Tripathy, S., Kale, S. D., Gu, B., Sheng, Y., Sui, Y., Wang, X., Zhang, Z., Cheng, B., Dong, S., Shan, W., Zheng, X., Dou, D., Tyler, B. M., and Wang, Y. 2011. Transcriptional programming and functional interactions within the Phytophthora sojae RXLR effector repertoire. Plant Cell 23:20642086.

Wang, Q., Liu, J., and Zhu, H. 2018. Genetic and molecular mechanisms underlying symbiotic specificity in legume-rhizobium interactions. Front. Plant Sci. 9:313.

Wang, Y., and Wang, Y. 2018. Phytophthora sojae effectors orchestrate warfare with host immunity. Curr. Opin. Microbiol. 46:7-13.

Weiberg, A., Wang, M., Lin, F. M., Zhao, H., Zhang, Z., Kaloshian, I., Huang, H. D., and Jin, H. 2013. Fungal small RNAs suppress plant immunity by hijacking host RNA interference pathways. Science 342:118-123.

Ye, W., Wang, Y., Tyler, B. M., and Wang, Y. 2016. Comparative genomic analysis among four representative isolates of Phytophthora sojae reveals genes under evolutionary selection. Front. Microbiol. 7:1547.

Zahran, H. H. 1999. Rhizobium-legume symbiosis and nitrogen fixation under severe conditions and in an arid climate. Microbiol. Mol. Biol. Rev. 63:968-989.

Zhang, L., Zhang, F., Melotto, M., Yao, J., and He, S. Y. 2017. Jasmonate signaling and manipulation by pathogens and insects. J. Exp. Bot. 68: $1371-1385$ 